\title{
On the origin of the Naiman
}

\author{
Tabyldy A. Akerov* \\ International University of Kyrgyzstan \\ 255 Chui, Bishkek, 720001, Kyrgyzstan
}

Received 13.03.2016, received in revised form 20.06.2016, accepted 15.08.2016

The work is dedicated to the problem of the origin of the medieval Altai ethnos of Naimans, who were able to form an early feudal state in Altai in the 12th century. The scientific literature ascribed them the Turkic, Mongol or Turko-Mongol origin. The work studies the issue of the origin of the Naiman in the context of studying the etymology of the ethnonym Naiman. It offers a new hypothesis of the emergence of the ethnonym Naiman among historical terms, which could have been inherited or borrowed from the eight constituent alliance of Kangar-Pecheneg tribes. The paper examines possible ethnopolitical and ethnogenetic, as well as ethnocultural ties of the Naiman with the Az, the Kangar-Pecheneg, the Kuchuk, the Tumat, the Oguz, the Khitan and other Altaic tribes. Based on the study, analysis and comparison of the version of the epic Manas described in the book Madzhumu at-Tavarikh by S. Akhsikendi with later versions of the great legend, the author makes an attempt to define the role and place of Naimans in the history of the Kyrgyz people and epic at the Altai stage of their development.

Keywords: Manas, the Naiman, the Kangar-Pecheneg, the Tumat, the Oguz, the Khitan, the Az, the Yenisei Kyrgyz, early feudal state, Buyruk Khan, Mogolistan, Altai, the Tien-Shan.

DOI: 10.17516/1997-1370-2016-9-9-2071-2081.

Research area: theory and history of culture.

The Naimans are an Altai people, who played a major role in the political life of Central Asia in the Middle Ages. They came from Altai. In the $12^{\text {th }}$ century Naimans formed their early feudal state in Altai. But so far in the academic world there has not been consensus on the issue of the origin of the Naiman. Some scientists wrote that the Naiman were Mongols, others wrote that they were Turkic-Mongols, a third group considered them to be Turks. But all scholars are unanimous that the Naimans were an eight constituent people. However, scientists have not still found a definite answer to the questions, such as which tribes were the core of the Naiman, whom they represented, if the Naiman society had more Turks or Mongols inside, etc. In this paper, we tried to find an answer to all these questions and tried to determine the ethnic ties of the Naiman with the Kangar-Pecheneg, the Kyrgyz, the Az, the Kuchuk, the Tumat, the Oguz, the Khitan and other Altaic tribes. Undoubtedly, our solutions can enhance the discussion on the topic, will raise its importance even more and will arouse an interest to the studied problem, which, of course, was one of the main goals and objectives of the research paper.

(C) Siberian Federal University. All rights reserved

* Corresponding author E-mail address: akttar@mail.ru 
I.N. Berezin linked the origin of the ethnonym Naiman with the Mongol numeral eight, which meant Segiz in Turkish and Neima in Mongolian. Hence, he believed, Naiman meant an alliance of eight tribes [7, 267]. V.V. Bartold confirms that the word Naiman in Mongolian means eight. Further, he says that this indicates the division of the nation into eight families [6, 104]. L.L. Viktorova [24], K.I. Petrov connected the origin of the Naiman with the Segiz Oguz. K.I. Petrov wrote, 'The numeral Naiman in the Mongolian language was consistent with the Turkic numeral Sekiz'. Originally, the tribe was named the Segiz Oguz, but later they came to be called the Naiman. The Segiz Oguz was part of the Union of the Toguz Oguz (Uighurs). Uighurs played a major role in the Union, while the Segiz Oguz was of a secondary importance $[19,72]$.

N.A. Aristov believed, that the ethnonym Naiman came from the name '... of the Naima river, the tributary of the Katun, and that they originally lived there' $[3,361]$ P. Carpini wrote that the Naiman had roamed '... in the vast area between the Khangai and the Altayn Nuru ridges, in the valley of the Black Irtysh and Lake Zaisannor' $[19,196]$.

L.N. Gumilev and some scientists considered the Naiman a northern branch of the Kara Khitan, who had refused to obey the Ye-lu Dashi and left for the Altai steppe. P. Rachnevsky wrote that the Naiman and the Kerait could have been part of the Kyrgyz people, or part of the ethnos of the Kyrgyz Khaganate [23, 103-104]. He was supported by E. Kychanov, who also saw a people of the Kyrgyz Khaganate in the Naiman, the Kerait, the Merkit and the Tatar [16].

V.V. Vostrov and M.S. Mukanov wrote that a part of the Naiman left with Prince Kushluk to the Pamirs and began to represent the Pamir Kyrgyz [25, 65].

V.V. Ushnitsky [23] turned his attention to the data of Rashid al-Din, where the medieval writer called the Naiman an old population of the Yenisei ousted from there by the Kyrgyz [21]. He was also interested in the fact that the Naimans like the Kyrgyz were engaged in agriculture, which distinguished them from other nomads of the north.

In general, the majority of scholars argued that the growth of political activity by a number of Turkic-Mongol tribes, namely, the Khitan, the Mongols, the Kerait, the Merkit, the Oirat, the Naiman and the Tatars, contributed to the appearance of the nomadic world's largest tribal alliances of the Naiman and the Kerait representing early feudal state formations in the $12^{\text {th }}$ century.

Rashid al-Din (the $13^{\text {th }}$ century) who was one of the first to report about the Naiman in detail, wrote, 'This is a steppe tribe: some lived in hard mountains, others in steppes ... They dwelled in the Big Altai, the Karakorum ... in the mountains of Aluy-Seras and Kek-Irtysh ... These Naiman tribes had their own venerable and powerful sovereigns; they had numerous and good troops; their customs and habits were like Mongolian. Their sovereigns in ancient days were called Kushluk Khan that meant a strong, great sovereign. The tribe Bikin was one of the tribes, which were close to the Naiman and whose yurts which were connected with their yurts' [21, 136-137], the Kipchak and the Kangly can also be noted. According to the Armenian king Gaiton, in the middle of the $13^{\text {th }}$ century the Naiman lived to the east of the Irtysh [10,522].

According to Rashid al-Din, the lans of the Naiman were located near the Kyrgyz area called Kem Kemdzhiut. He wrote, 'One side of Kem Kemdzhiut adjoins the countryside and mountains, where the Naiman tribes dwell. The tribes of Kori (Fuli by T.A.), Bargu, Tumat and Baiaut, some of which are Mongols and inhabit in the Barkudzhin-Tokum location, are also close to this area' $[12,151]$. According to the 
source, Barkudzhin Tokum was close to KemKemdzhiut.

According to sources, the Naiman in the west neighbored with the Kangly and the Kipchak, who lived in the upper reaches of the Irtysh River, in the north they did with the Yenisei Kyrgyz, in the east - with the Kerait who lived in Eastern Mongolia, and in the south - with the Uighurs. They had especially close ethnopolitical and cultural ties with the Kangly. According to some data, the groups of the Kangly and the Kipchak settled in the lands of the Naiman.

Traditionally, the origin of the Naiman is associated with the Segiz-Oguz by those who believe that the ethnonym Naiman was a Mongolian calque of the numeral name of tribes living in the area of Vosmirechye in Western Mongolia. In this regard, the Naimans were seen as a union of the eight tribes.

However, we consider the opinion of the scientists who saw a part of the ethnos of the Kyrgyz Khaganate in the Naiman to be fairer. It is important that the Naiman had close ethnogenetic ties with the tribes related to the Yenisei Kyrgyz. It means, the tribes of Kyrgyz, Kangar-Pecheneg, Az, Kuchuk and Oguz, who recognized the authority of the Kyrgyz people after the events of the year of 840 , could have played a major role in the ethnogeny of the Naiman.

It should be noted that, according to Rashid al-Din, the Naiman and the Kangly were neighbors in Altai. In The Secret History (the $13^{\text {th }}$ century) in Vosmirechye (Segiz-muren), where the ancestors of the Naiman could have lived, the Tumat (the Tumaut) who were the descendants of the Dubo, settled. This union of Dubo tribes along with the Dubo family originally included the Melige (the Merkit), the Echzhi / the Kanggach-Kangar.

However, the information of the sources telling about the relationship of the Naiman with the Altai Kuchuk is no less interesting. According to it, the Kuchuk had kinship relationship with the Naiman. One of the women of Arik Buka came from the Kuchuk family of the Naiman tribe. The Kuchuk like the Naiman lived close to the Kyrgyz and the Az and had close ethnic and ethnogenetic relationships with them. According to the ethnographic data, it is found out that the Altai Naiman (the Maiman) considered a dog to be their ancestor [21, 17-1.]. It means a dog was the Naiman's totem.

It seems to us, the Naiman tribe also had ethnic ties with the Oguz-Turkic group of tribes. Obviously, our latter opinion is supported by the ethnonym totosh (tardush) and naymanak occured in the structure of the family of the Totosh Altai, as well as tardush found in the tribal structure of the Kyrgyz tribe Kytai (akin to the Naiman). It is possible that the Khitan and the Naiman could have been ethnically close to each other due to the existence of the tribes of the Turkic-Oguz group in their structure, which had played an important role in the region until 840, when the Yenisei Kyrgyz defeated the Toguz Oguz and established their dominance over Central Asia. In the era of the Great Kyrgyz Khaganate the ancestors of the Naiman and the Khitan might have had some kind of relationship with the Toguz Oguz. Therefore, the information from historical sources speaks more in favor of the Turkish origin of the Naiman. It is possible that the Naiman borrowed its ethnic name from the Kangar-Pecheneg. The Union of the Kangar-Pecheneg tribes consisted of eight major tribes and forty families.

In medieval sources the Kangar-Pecheneg, the Az and the Kyrgyz were marked as neighbors in Altai. It is known that they were related groups. The Kyrgyz could also have had family ties with the Kangar-Pecheneg. It is no coincidence that the Kangar-Pecheneg, as well as the Az and the Kyrgyz were considered the tribes, coming from forty families.

We believe that the Kangar-Pecheneg were the western group of the Yenisei Kyrgyz. The 
emergence of the Kangar-Pecheneg union on the historical arena coincided with the strengthening of the Kyrgyz Khaganate at the Yenisei. Obviously, at that time, some groups of Kyrgyz people separated from the main body, and began to live to the west of them.

During the domination of the Yenisei Kyrgyz at the Sayano-Altai, the Yenisei Kyrgyz were ruled by the Az or Us family. Azho from the Az family was at the head of the state. The Chinese chronicles cite a legend about the link of the $\mathrm{Az}$ with the Kyrgyz. According to the legend, the Kyrgyz allegedly came from 40 (ancestors) girls of the Han land, got married to men of the Us family. Since then, the country was renamed the Kyrgyz land [18, 146-151]. Perhaps, that is why the leaders of the Naiman following the example of their ancestors added the Kyrgyz ethnonym $A z(A s, U s)$. For example, Tayan, the son of the Naiman Khan (in the $12^{\text {th }}$ century) was named Us Segiz Kuchluk Khan.

According to sources, the Naiman, just like the ancient Az, neighboured with the Kangly in Altai. They both were always mentioned together with the Kyrgyz. Like the Az, the Naiman came from Western Mongolia.

According to the runic inscriptions, during ancient Turkic times the Az lived in in the southeastern Altai and Sayan, namely in the river heads of the Alash, the Ak-Sug and near Lake Kara-Khol, and were in the sphere of influence of the Eastern Turkic Kagan. Based on the inscription made in honor of Kul-Tegin, B. Mongush notes that Kok-Turks, conquering the territory of modern Tuva and adjacent Altai lands, fought with the Az three times. Each time happened in different places of the Sayano-Altai Territory and Western Mongolia. The first time was at the coastal lands with the Chiki in Tuva, the second time was near the Black Irtysh, and the third time was at Kara-Khol.
B. Mongush writes, 'The Az roamed over a vast territory, particularly in the Altai Mountains, Western Tuva and Khakassia-Minusinsk steppes. At the same time it can be assumed that the two branches of this people are mentioned, namely, the Sayan branch (the Steppe Az), who lived in the steppes of the Khakassia-Minusinsk depression, and the Altai branch (the Mountain Az), who lived in the territory of the Altai Mountains and Western Tuva' [18, 146-151].

Most scientists are inclined to attribute the Irtysh Az to the Turgesh. In the Middle Ages the Az migrated from east to west, and came to the Crimea. The Az lived in Semirechye, Central Asia and the North Caucasus. In the $10^{\text {th }}$ century sources reported about a group of the Az dwelling in the areas of the medieval city Horrezm. The book Chingiz-name by Utemish Khodzhi [22] calls the group of the Az Az-shirin. They had strong ethnopolitical ties with Altai tribes in the Mongol period. The Az-shirin had chomuch (a bucket) as a tamga. The author also informs about the alliance of Toktamysh Khan with the tribes of the Az-shirin, the Kipchak, the Argyn, the Bakhrin $[2,27]$. The same information is repeated in the version of the epic Manas by S. Ahsikendi, where a much more expanded list of allies of Toktamysh Khan was indicated. According to Ahsikendi, Khan had an alliance with the Mogolistan Prince Anga Tore, the leader of the Kyrgyz Manas, as well as Kipchak, Argyn and Bahrin tribes [4, 45]. The above noted information is supported by the information of Merverrudi, where the Az are included in the list of the peoples of Central Asia of the Pre-Mongol period, that, above all, says that the Az very quickly recovered from the attack of the Kara Kitai in the $12^{\text {th }}$ century and had had an independent public formation by the beginning of the Mongol invasions (the $13^{\text {th }}$ century).

In this case, the above once again confirms the correctness of the views of the scientists linking the Naiman with the Altai Az. 
The Naiman lived in the same areas where the Az lived. In the $8^{\text {th }}$ century the Naiman lived to the south of Lake Baikal. In the middle of the $9^{\text {th }}$ century the Naiman tribes roamed from the Orkhon to the Tarim and the Black Irtysh. In the Mongol period, they moved to the North Caucasus and Turkey. Naimans as well as Az Shirins were part of the Golden Horde.

The collected ethnographic materials indicate that the Naiman inherited chomush (a bucket) as the family tamga and the totem of the Altai Kuchuk from the Az Shirin [12, 17-18]. It is important to note that the overall family tamga of the Naiman, namely, chomuch/shomish (a bucket), was kept by the Kyrgyz and the Kazakh Naiman, who live virtually in all the ancient territories of the Az Shirin. It is noteworthy that the tribal groups, who kept the names of the medieval Altai tribes, including the Az, the Kuchuk, etc., were found in the structure of the Naiman families. For example, the Caspian Nogai (the $19^{\text {th }}$ century) Naiman had such families as the Uskyube (Kubsettlemet Us), the Bakay ulu, the Turkish Naiman had such a family as the Kuchuk-Naiman, the Kyrgyz Naiman had a family of Narai-Naiman (compare with Narba-Khakass), the Chandyk (compare with the Shandin family of the Yenisei Kyrgyz and the Sandyrdyr-fuiui Kyrgyz), the Tuuma Tukum (the Ancient Tumat), and the Kazakh Naiman had Segiz Sary, Bura-Naiman, Kara Kirei-Naiman families and so on.

In the $12^{\text {th }}$ century the Naiman increased. By this time Barkudzhin Tokum had become very mixed in ethnopolitical terms. Rashid alDin wrote that Bargut (the Bargu), the Kori, the Tolos (the Dolos), the Tumat were related families, called the Bargut, because they lived on the other side of the Selenga river. In this regard, the area where the latter inhabited was called Barkudzhin-Tokum. The leaders of the tribes of Bargu, Tolos and Tumat bore the title of Inal. According to Rashid al-Din, the Bargu, the Kuri and the Kyrgyz had close ethnopolitical relations. The tribes, related to the Kurlaut, the Kungirat, the Edzhigin, having the common tamga and preserved phratrial relationship, were also called the Bargut. Referring to Rashid al-Din, K. Petrov designated the Tolos, the Kuri (the Alakchyn), the Bulgachi and the Keremuchin as the tribes of Barkudzhin Tokum. The latter were also called the Bargut [20, 23].

For a short time they took control of a vast territory, stretching from the Irtysh and Altai to Baikal region (the Barkudzhin Tokum area), in other words, from the lands of the Kerait in Altai to the farthest Kyrgyz lands of the Bulgachi and the Keremuchin in the east.

We shall note that the tribes of Bulgachi had a great influence on the peoples of Southern Siberia. For example, the Zakamensk Buryat and their shamans called the scene of a tribal rite Bulgan teebi. During the rite hare skins, treated by shamans and considered to be a talisman of children, were hung everywhere in a prominent place. According to G.N. Potanin, the Alear Buryats called their ongon Bulgasha or Bulgasha Khan. The image of a woman with nine tambourines, who was able to transform into someone else, dominated in Buryat tribes. Usually shamans acted as a talisman of children.

In the Mongol period the community of Naiman tribes could have included Kyrgyz unions of the Bulgachi and the Keremuchin. According to some reports, they migrated to the Tien Shan in the $13^{\text {th }}-14^{\text {th }}$ centuries together with the Naiman. In the Naiman environment the Bulgachi (from the word bulgachi that means firebrand, rebel, rebellious) stood out due to a collective name Bulgachi-Naiman. By the age of Timur, the Bulgachi together with the related Saluchi had managed to form their ulus named SaluchiBulgachi in Mogolistan. The Keremuchin lived there as a part of Kyrgyz tribes [17, 206]. 
A number of historical sources provided the information that confirmed the migration of the Naiman and other tribes to the Semirechye during the Mongol invasions. Xiyu Zhi mentioned Naimans as a part of Kyrgyz tribes of the union of the Bulgachi-ichkilik along with the Keremuchin, the Kipchak, and others who had the common history and culture in Altai. Xiyu Zhi cites the name of the group of Kyrgyz families of the Kipchak-Burut, namely, Karadzhaydak, Yaman Teyit, Kyzyl Ayak, Toru Aygyr, Sart Kipchak, Kyzyl Kipchak, Noygut, Kara Teyit, Sarya Teyit, Chal Teyit, Naiman, Keke Naiman, Keremuchin, Sary Naiman, Kyzyl Naiman [17, 206].

The structure of the Ferghana Kyrgyz and Uzbeks still has such names of families as Bulgachi-Naiman. S.M. Abramzon wrote about the existence of a small family called BulgachiNaiman as a part of the Shaarikhana Naiman (Uzbekistan). According to him, earlier the Bulgachi-Naiman were a large group, but as a result of hunger, many of them left for Gissar (Ysar), remained to live there and later became known as Kaldyk-Naiman (Kaldyk or Karlyk) [1, 49].

In the era of the Kyrgyz Greatpowerness, the ancestors of the Naiman, the Kerait, the Merkit and the Tatars were part of the Kyrgyz Khaganate. Later the latter continued to represent the Kyrgyz in Altai and Western Mongolia as independent unions. Obviously, the Naiman and the Kerait were governed by the representatives of the Kyrgyz aristocratic family of the Edi and the Az.

This is proved by direct indications of sources. Firstly, the Naiman neighbored with the Kangly in the upper Irtysh [14, 63]. Both unions were in close ethnopolitical and ethnogenetic relations with the Kyrgyz. The recent scientific studies have shown that, 'The lands of the Naiman extended from the upper reaches of the Selenga and Orkhon to Tarbagatai from east to west, from the Tannu-Ola mountains to the eastern spurs of Altai from north to south-east' [23, 24]. In other words, they took a larger area of the former lands of the Az and the Kangly.

Secondly, in Vosmirechye (Segiz-muren), where the ancestors of the Naiman must have lived, the Tumat (the Tumaut), the descendants of the three consistuent tribe Dubo (Dubo, Melige, Echzhi / Kangach-Kangar) lived. Thirdly, the medieval sources point to the relationship of the Kerait with the Kangly. Fourthly, Rashid al-Din wrote about the Kerait, 'They are kind of the Mongols; have their habitations along the Onon and Kerulenu rivers, which were the land of the Mongols' [21, 127]. In other words, the Kerait could have been one of the Kyrgyz tribes, which had represented the Kyrgyz in Mongolian steppes earlier. In the epic Manas by S. Ahsikendi Ong Khan (Wang Khan the Kerait) was an ally of Manas and the Kyrgyz. He came from the tribe of Kara Yetti (Edi) and ruled the state of Kara Yetti (powerful Edi-seven) [4, 36].

Naimans took part and played an important role in the creation of the union of Tszubu tribes. According to Liao Shi, after the fall of the hegemony of the Uyghurs and during the Kyrgyz-Kara Khitan confrontations in the east of the Yenisei Kyrgyz, a new alliance of Tszubu tribes, the backbone of which were Mongolianspeaking and Turkic-Mongol tribes of Shivei, Tatars, Naimans, Merkits and Keraits, was formed. The main purpose of the formation of a new tribal alliance was confrontation to the expansion of the Kara-Kitai. In this regard, the new confederation like a three-wing management system was formed. The Keraits were a central group in the Tszubu, the Naimans were a northwestern group and the Merkits were a northern group. Apart from them, there was also a group of Sogdians (Sog-po) [5].

In $12^{\text {th }}-13^{\text {th }}$ century, during the confrontations of the Khitan and the Kerait, who headed the 
union of Tszubu tribes, steppe tribes were divided into three major warring forces. The first group of tribes was headed by the Khitan and the Naiman, the second one was headed by the Kerait and the Kyrgyz, who at that time began to consolidate mainly in two Kyrgyz lands, located along the middle reaches of the Yenisei River and Kemkemdzhiut in Western Mongolia. The third group was Mongol tribes, who were on friendly terms with the Kerait on a parity basis. Moreover, the Kerait, who had ethnopolitical ties with the Kyrgyz in the era of the domination of the Khitan, gladly rendered great services to Genghis Khan at the beginning of his political career, which could indicate the existence of ethnopolitical and ethnogenetic connections of the Golden Horde with them in the past.

According to Yu.S. Khudyakov, the Naiman in the $12^{\text {th }}$ century occupied areas of Western Mongolia, including the Ektag-Altay ridge. In the middle of the $12^{\text {th }}$ century Naiman leaders Narkysh Tayan and Eniyat Kaan 'broke a Kyrgyz tribe', which lived 'in the Kyrgyz area, on the border with the Irtysh river and the desert, adjacent to the country of Turfan Uighurs' [13, 73]. However, in 1199 the Naiman Buyruk Khan was defeated by Genghis Khan and was forced to flee to the Kyrgyz region of KemKemdzhiut. After a crushing defeat, fearing of retaliation, the Naiman Khan did not stay long in the Kyrgyz lands. Buyruk Khan went to the Irtysh, squeezing out the Kerait to the steppes of Mongolia and Dzhungaria. Obviously, the route Kem-Kemdzhiut-Irtysh of Buyruk Khan can justify the correctness of our opinion about the kinship of the Naiman and the Az. The Naiman Khan from Kem-Kemdzhiut could easily have got to the Irtysh through the land of the Az in Tuva, which led to Altai. Perhaps, that is why the Nogai Naiman had the Az family in their structure.

We believe that after being defeated by the Naiman, one of the groups of the Kerait could have gone to the Tien Shan, hiding in Jungar steppes. However, a little later, the Naiman, who could not repel the onslaught of the Mongol hordes, followed the Kerait.

According to sources, Kuchlug Khan, the son of Tayan Khan, who was killed in a battle, tried to unite the Naiman, the Kerait, the Onguto and other tribes. In 1218 the young prince Kuchluk was supported by the Yenisei Kyrgyz and the Tumat, as well as the Merkit, who rebelled against the Mongolian expansion. The allies were defeated one by one. Kuchluk fled to the west and took refuge at the Kara Chinese Gurkhan in the Tien Shan. But later Kuchluk was caught and beheaded by Zhebe Noyon, who had been specially sent by Genghis Khan to capture and destroy him. After his tragic death, the leadership passed to the descendants of Van Khan the Kerait again.

In our view, the events of the epoch of KeraitKara Chinese struggles albeit with a certain stratification, but still are well described in the version of the epic Manas by S. Ahsikendi and its later versions. The above-mentioned events are described there as a confrontation between the Kyrgyz and the Kara-Kitai.

We shall note that the version of Manas by S. Ahsikendi is entirely devoted to the history of the development of Kyrgyz-Kerait relationship during the period of the Khitan and Mongol domination. The Kerait as part of the Mongol state continued to have strong ethnopolitical and ethnogenetic ties with the Kangly, the Kyrgyz and the Kipchak. The events reflected in Manas by S. Ahsikendi characterize the period of the revival and strengthening of the ethnopolitical relations of the Kyrgyz with the Kipchak, the Kerait, Mongols and other tribes within the Golden Horde and Mogolistan. Manas by S. Ahsikendi assigns a major part to Ong Khan (the leader Wang Khan the Kerait) [4, 35-36]. Ong Khan consistently provided support and assistance to 
the young Dzhakypbek, the governor of Karkyra country. His quarters Kara Kyshtak were located in the valley of the Talas river [4, 43-66], where Baatyr Manas was born. The important point is that albeit with strata, it has kept the stories of the Kyrgyz migration together with the Kerait and Mongols to the west due to the conquests of Genghis Khan in Central Asia.

At the same time, all versions of the legend indicate an epic hero Zholoy, whose name scientists identified with the name of Yelu Dashi, the gurkhan of the Kara Kitai, who was the main opponent of Wang Khan, as one of the main enemies of Manas. Obviously, in this case, we find the reflection of the era of confrontation between the two great powers in Central Asia in the story, namely the Kerait and the Kara-Kitai, which played an important role in the fate of the Kyrgyz people and the epic Manas.

It is most likely that the version of the epic Manas by S. Ahsikendi can be called the Kerait version of the great legend. Our opinion, first of all, is proved by the fact that if we do not find the Naiman in the list of the names of Manas's allies in the version of Manas by S. Ahsikendi, the later versions of the epic Manas did not mention the names of Kerait Wang Khan and Anga Tore who were the main allies of Manas. However, if the version of the epic Manas by S. Ahsikendi mentioned the tribes of Saluchi-Bulgachi, which included the Doolos, the Teit, the Kesek, the Zhoo kesek, the Boston, the Kydyrshah as the allies of Manas, the later versions of the legend indicated the latter along with the Altai families of the Naiman and the Kipchak as Kyrgyz unions.

Therefore, we find the existence of at least two versions of the epic Manas in the Mongolian period, namely the Kerait and the Naiman versions, which were developed on the basis of the Altai version and after the formation of the confederation of Tszubu where the two associations played an important role in the history of Central Asia.

According to Chinese chronicles, the Naiman of $12^{\text {th }}-13^{\text {th }}$ centuries had ethnopolitical connections with the Ongut and together with the latter fitted the concept of White Tatars. The epic Manas mentioned the Ongut as Noygut and presented them as a Kyrgyz tribe maternally related to Manas. The mother of Khan Manas belonged to the tribe of Noygut. The legend referred the Noygut and the Naiman, the Nogai, the Kangy (Kangly), the Kipchak, the Doolos, the Argyn and other Altaic tribes collectively to Kyrgyz unions.

Thus, based on the foregoing, it can be assumed that in the period of Kyrgyz-Kara Chinese struggles, the Naiman grouped more together with the Kara Kitai. However, after the events in 1199, when Buyruk Khan established a complete domination of the Naiman in Altai, squeezing the Keraits out of there to Mongolian steppes, Altai tribes rallied around the leaders of the Naiman, which ensured the emergence of the Naiman version of the epic Manas.

But this did not prevent the Kerait, who had moved to Semirechye by that time, from saving their own version of the epic Manas, written by S. Ahsikendi. The Kerait and the Kyrgyz, allied with them, as well as the Kipchak exported Manas to the Tien Shan, where they formed a new state Mogolistan.

Thus, from the above we can conclude that the ethnonym Naiman could really have been associated with the numeral eight, but it carriers could have inherited or borrowed this name from the Kangar-Pecheneg, their western neighbors, which consisted of eight major tribal groupings. Naimans had a variegated ethnic structure. The Kangar-Pecheneg, the Az, the Kuchuk, the Tumat, the Kyrgyz, the Oguz (the Turkic Oguz) and the Khitan played an important role in their ethnogeny. We also do not rule out that the Khitan 
and the Naiman could have been ethnically close to each other due to the existence of the TurkicOguz group, whose ancestors were part of the Great Kyrgyz Khaganate, in their tribes.

It is important to emphasize that prior to the $12^{\text {th }}$ century the Naiman had played a secondary role in the Union of Tszubu tribes. However, since 1199, when Buyruk Khan defeated the Kerait and expelled them to the Mongolian steppe, the Naiman became leaders in the group of the tribes, which were part of the Tszubu and Altai Union earlier that is confirmed by the data of the later versions of the epic Manas. The hegemony of the Naiman in Altai continued after the events of 1204, when Genghis Khan defeated the combined forces of the Naiman and Jamukha against the Mongol ruler. The flight of Buyruk Khan to the Kyrgyz Kemkemdzhiut region in 1199, as well as the Yenisei Kyrgyz's attempt to reunite with Prince Kuchluk, point to the existence of close ethnopolitical and ethnogenetic relations of the Naiman with the Kyrgyz and the tribes of Altai related to them.

\section{References}

Abramzon, S.M. (1990). Kirgizy i ikh etnogeneticheskie i istoriko-kul'turnye sviazi [The Kyrgyz and their ethnogenetic and historical-cultural ties]. Frunze.

Akerov, T.A. (2014). Kyrgyzy: etnogenez $i$ istoriia [The Kyrgyz: ethnogeny and history]. Bishkek.

Aristov, N.A. (1896). Zametki ob etnicheskom sostave tiurkskikh plemen i narodnostei i svedeniia ob ikh chislennosti [Notes on the ethnic composition of the Turkic tribes and peoples and an indication of their number], 4 \& 5. Saint-Petersburg, Zhivaia Starina.

Akhsikendi, Sayf al-Din. (1996). Tarykhtardyn zhyinagy (Mazhmu atut Tavorikh). Baghdad.

Avliaev, G.O. (1984). K voprosu o proiskhozhdenii kereitov i ikh uchatii v etnogeneze srednevekovykh oiratov Dzhungarii i kalmykov Povolzh'ia [On the origin of the Kerayit and their participation in the ethnogeny of the medieval Oirat of Dzungaria and the Kalmyk of the Volga region], In Problemy etnogeneza kalmykov [The problems of the ethnogeny of Kalmyks]. Elista.

Bartold, V.V. (1968). Sochineniia [Works], 5. Moscow.

Berezin, I.N. (1858). Ocherki vnutrennego ustroistva ulusa dzhuchiev [The essays on the internal structure of the Jochi Ulus], In Trudy vostochnogo otdeleniia imperatorskogo arkheologicheskogo obshchestva [Proceedings of the Eastern Branch of the Imperial Archaeological Society], 5. St. Petersburg.

Grumm-Grzhimailo, G.E. (1926). Zapadnaia Mongoliia i Urankhaiskii krai [Western Mongolia and Urankhai region]. Leningrad.

Dzhumanaliev, T.D. (2007). Khrestomatiia po srednevekovoi istorii Kyrgyzstana [The Reader on the medieval history of Kyrgyzstan], 2. Bishkek.

Iamaeva, E.E. (2004). Rodovye tamgi altaiskikh tiurok (XIX-XX vv.) [The family tamga of the Altai Turks $\left(19^{\text {th }}-20^{\text {th }}\right.$ centuries)]. Gorno-Altaisk.

Khudyakov, Yu.S. (1995). Kyrgyzy na prostorakh Azii [The Kyrgyz in the vast Asia]. Bishkek.

Kliashtornyi, S.G. (1951). Kangiuiskaia etnotoponimika v orkhonskikh tekstakh [The Kangui ethnotoponymy in Orkhon texts], 3. Sovetskaia etnografiia.

Kychanov, E. (1990). Iuan'-Min doorundagy kyrgyzdar (XIII-XV-kylymdar) [Yuan-Ming doorundagy kyrgyzdar $\left(13^{\text {th }}-15^{\text {th }}\right.$-kylymdar), In Ala Too [Ala Too], 7. Frunze. 
Kychanov, E. (2003). Velichie i padenie Kirgizskogo kaganata [The greatness and the fall of the Kyrgyz Khaganate], In Slovo Kyrgyzstana [The Word of Kyrgyzstan], 20.

Materialy po istorii kyrgyzov i Kyrgyzstana [Proceedings on the history of the Kyrgyz and Kyrgyzstan], 2. (2002).

Mongush, B.B. Proiskhozhdenie azov i aziiskii component $\mathrm{v}$ etnogeneze tuvintsev (po vostochnym pis'mennym istochnikam) [The origin of the Az and the Az component in the ethnogeny of the Tuvan (based on oriental written sources)], In Vestnik Tomskogo gosudarstvennogo universiteta. Istoriia [Bulletin of Tomsk State University. History], 1013 (23).

Petrov, K.I. (1963). Ocherk proiskhozhdeniia kirgizskogo naroda [The sketch of the origin of the Kyrgyz people]. Frunze, Izdatel'stvo AN Kirgizskoi SSR.

Petrov, K.I. (1961). K istorii dvizheniia kirgizov na Tien'-Shan' i ikh vzaimootnosheniia s oiratami [On the history of the movement of the Kyrgyz to the Tien Shan, and their relationship with Oirats]. Frunze.

Puteshestviia v vostochnye strany Plano Karpini i Rubruka [Travelling to the Oriental countries of Plano Carpini and Rubruk]. (1957). Moscow.

Rashid, al-Din. (1952). Sbornik letopisei. Per. s persidskogo L.A. Khetagurova [The Collection of Chronicles. Transl. from Persian by L.A. Khetagurova], 1 (1). Moscow, Leningrad, Izd-vo AN SSSR.

Sandag, Sh. (1970). Obrazovanie edinogo mongol'skogo gosudarstva i Chingiskhan [The formation of the unified Mongol state and Genghis Khan], In Tataro-mongoly v Azii i Evrope [Tatar-Mongols in Asia and Europe]. Moscow, Glavnaia redaktsiia vost. lit. izd-va Nauka.

Utemish-Hadzha. (1992). Chingiz-name [Genghis-name]. Alma-Ata.

Ushnitsky, V.V. (2013). Naselenie Baikal'skogo regiona v epokhu srednevekov'ia (k probleme proiskhozhdeniia Sakha) [The population of the Baikal region in the Middle Ages (on the problem of the origin of the Sakha)]. Yakutsk.

Viktorova, L.L. (1961). K voprosu o naimanskoi teorii proiskhozhdeniia mongol'skogo literaturnogo iazyka i pis'mennosti XII-XIII vv. [On the issue of the Naiman theory of the origin of the Mongolian literary language and script of the 12th-13th centuries], In Uchenye zapisi LGU. Seriia vostokovedcheskikh nauk [Proceedings of LSU. A series of Oriental Sciences], 305 (12).

Vostrov, V.V., Mukanov, M.S. (1968). Rodoplemennoi sostav i rasselenie kazakhov (konets XIXnachalo XX v.v.) [The tribal structure and resettlement of Kazakhs (the late 19th-early 20th centuries)]. Alma-Ata, Nauka.

\title{
К вопросу о происхождении \\ найманов
}

\author{
T.А. Акеров \\ Международный университет Кыргызстана \\ Кыргызская Республика, 720001, Бишкек, Чуй пр., 255
}

Статья посвящена проблеме происхождения средневекового алтайского этноса найманов, которые в ХІІ веке смогли сформировать свое раннефеодальное государство на Алтае. В научной литературе им приписывали одни тюркское, другие монгольское, а третьи тюрко-монгольское 
происхождение. Вопрос о происхождении найманов исследуется в контексте изучения этимологии этнонима «найман». Предлагается новая гипотеза появления на историческую арену этнонима «найман», который мог быть унаследован или заимствован от восьмисоставного союза племен кангаро-печенегов. Рассматриваются возможные этнополитические и этногенетические, этнокультурные связи найманов с азами, кангаро-печенегами, кючюками, туматами, огузами, киданями и другими алтайскими племенами. На основе изучения, анализа и сравнения версии эпоса «Манас» приведенной в книге С. Ахсикенди «Маджуму ат-Таварих» с более поздними вариантами великого сказания делается попытка определить роль и место найманов в истории кыргызского народа и эпоса на алтайском этапе их развития.

Ключевые слова: «Манас», найманы, кангаро-печенеги, туматы, огузы, кидани, азы, енисейские киргизы, раннефеодальное государство, Буйрукхан, Моголистан, Алтай, Тянь-Шань.

Научная спеииальность: 24.00.01 - теория и история культуры. 